\title{
OGRODY LECZNICZE JAKO FORMA WSPOMAGANIA TERAPII
}

\author{
Michał Dmitruk \\ Katedra Architektury, Urbanistyki i Planowania Przestrzennego, Wydział Budownictwa i Architektury, Politechnika Lubelska \\ Department of Architecture, Urban and Spatial Planning, Faculty of Civil Engineering and Architecture, University of Lublin \\ e-mail: m.dmitruk@pollub.pl
}

\begin{abstract}
Streszczenie. Bliskość natury zawsze wywierała pozytywny wpływ na zdrowie człowieka i jego dobre samopoczucie. Od czasów rewolucji neolitycznej, zapoczątkowanej 10000 lat przed naszą erą i rozpoczęcia procesu przechodzenia z łowiectwa i zbieractwa do osiadłego trybu życia, świętym ogrodom, gajom czy formacjom skalnym zaczęto przypisywać mistyczną moc. W średniowieczu, stałymi elementami zespołów klasztornych były ogrody. Zarówno te ziołowe o funkcji czysto pragmatycznej - leczniczej, jak i ogrody rekreacyjne i wypoczynkowe - jako miejsce sprzyjające kontemplacji i zadumie. Wraz z rozwojem cywilizacyjnym, obecność ogrodów w przestrzeni osadniczej człowieka stała się trwałym elementem krajobrazu. Zauważono ich dobroczynny wpływ na psychikę i stan zdrowia człowieka, jak i doceniono walory czysto estetyczne.

Wraz z rozwojem nowoczesnych technik medycznych, uzdrawiająca rola ogrodów została zmarginalizowana, bądź zupełnie pominięta. Skupiono się na czysto fizjologicznych efektach terapii a niezwykle istotny aspekt psychologii w przebiegu leczenia uznano za drugorzędny. Obecnie wiemy, że stan psychiczny pacjenta ma niejednokrotnie kluczowy wpływ proces zdrowienia. W Stanach Zjednoczonych Ameryki Północnej, w Kanadzie, jak i w niektórych krajach Europy Zachodniej ogród jest nieodłącznym elementem planu budynków służby zdrowia. Służy on nie pracownikom, ale przede wszystkim pacjentom, w celach wypoczynkowych i relaksacyjnych co ma wymierne przełożenie na proces rekonwalescencji. Zaplanowany jest w sposób pomagający wyzbyć się stresu i obciążeń psychicznych związanych z chorobą, dający poczucie spokoju i bezpieczeństwa.

W Polsce ogrody lecznicze, towarzyszące budynkom szpitali czy przychodni nie są uważane za niezbędny element ich architektury, a zasady kompozycyjne takiej przestrzeni nie są dla wszystkich projektantów znane, bądź czytelne. Pojawia się więc konieczność edukacji społecznej, a wśród architektów pojawienia się trendu, skupionego na umiejscawianiu takich przestrzeni w towarzystwie budynków opieki medycznej i traktowaniu ich jako element nieodzowny. Korzyści zdrowotne dla pacjenta $\mathrm{z}$ takich udogodnień jakimi są ogrody lecznicze są niewspółmierne do kosztów ekonomicznych. A przecież to zdrowie jest najcenniejsze.
\end{abstract}

Słowa klucze: przestrzeń publiczna, projektowanie zieleni, ogród leczniczy, stres, zdrowie rehabilitacja, leczenie

Jak mawiał znany architekt krajobrazu, autor Projektu Central Park na Manhattanie - Frederick Law Olmsted, „Ogród zajmuje umyst bez jego wysilania, uspokaja, a jednocześnie ożywia. Przez co odświeża i dodaje wigoru"”.

Koncept leczniczych ogrodów jest ideą mającą swoje korzenie w przeszłości. Począwszy od czasów prehistorycznych, od tzw. rewolucji neolitycznej², poprzez wszystkie późniejsze epoki historyczne, kręgi kulturowe i szerokości geograficzne ogrody towarzyszyły ludzkości jako miejsca kultu, odpoczynku czy wyciszenia. Ich mistyczny charakter i niezwykły urok był powszechnie zauważany i doceniany. Słynne ogrody Persji, japońskie ogrody Zen, czy przyklasztorne ogrody średniowiecznej Europy łączy wspólna cecha - były miejscem odnowy i regeneracji, zarówno psychicznej, jak i fizycznej. Perskie ogrody stanowią jeden z najlepszych przykładów architektury krajobrazu i interakcji człowieka z przyrodą. Kształtowane już w VI wieku przed naszą erą na terenach dzisiejszego Iranu, ogrody stanowić miały formę oazy na pustyni - miejsca bezpiecznego i odprężającego. Formowane były na bazie symetrycznych, mocno zgeometryzowanych układów, z dwiema głównymi osiami, przecinającymi się

1 Rybczyński W., 1999. A Clearing in the Distance: Frederick Law Olmsted and North America in the Nineteenth Century. Nowy Jork, Thumaczenie autorskie.

2 Hensel W., Tabaczyński S., 1978. Rewolucja neolityczna i jej znaczenie dla rozwoju kultury europejskiej. Zakład Narodowy im. Osolińskich, Wrocław-Warszawa-Kraków-Gdańsk. 
po środku ogrodu, co dawało poczucie ładu i harmonii. Na przecięciu się osi symetrii często znajdowała się fontanna. Ogrody niejednokrotnie otoczone były wysokim murem, wewnątrz oprócz alejek znajdowały się punkty wodne, wzgórza, czy niewielkie pawilony. Ogród miał skłaniać do refleksji a także do nawiązywania kontaktów społecznych. Średniowieczne ogrody przyklasztorne zakładane główne przez zakony Benedyktynów, Cystersów, Dominikanów i Franciszkanów. Przybierały formę, zamkniętych i otoczonych murami (niekiedy krużgankami) niewielkich kwadratowych dziedzińców ${ }^{3}$, podzielonych alejami na kwatery przecinającymi się pod kątem prostym ścieżkami i kojarzonymi niejednokrotnie z czteroma kardynalnymi cnotami: (męstwem, roztropnością, sprawiedliwością i umiarkowaniem). W poszczególnych kwaterach sadzono zioła, takie jak bazylia, szałwia, rozmaryn czy lawenda, a także kwiaty: tulipany, goździki, fiołki i lilie. Ogród w formie wirydarza, przylegającego do innych zabudowań klasztornych był miejscem niezwykle ważnym - sprzyjał skupieniu i modlitwie, a także posiadał wiele istotnych cech użytkowych - dostarczał zioła i warzywa niezbędne w żywieniu i lecznictwie. Ogród wyposażony był również w takie elementy jak ławy, elementy ozdobne, fontanny lub studnie. Japoński ogród Zen w swoich wytycznych kompozycyjnych zakładał wkomponowanie w przestrzeń ogrodu wszystkich aspektów natury i żywiołów przyrody, czy to w sposób dosłowny, czy na zasadzie skojarzeń. Zgodnie z filozofią Zen, ogród miał symbolizować spokój, równowagę w przyrodzie, porządek czy nawet podróż przez życie. Ta subtelna metaforyka i delikatna narracja, prowadzona za pomocą aranżacji w przestrzeni różnych elementów przyrody działała na odbiorcę kojąco, jednocześnie pobudzając do refleksji.

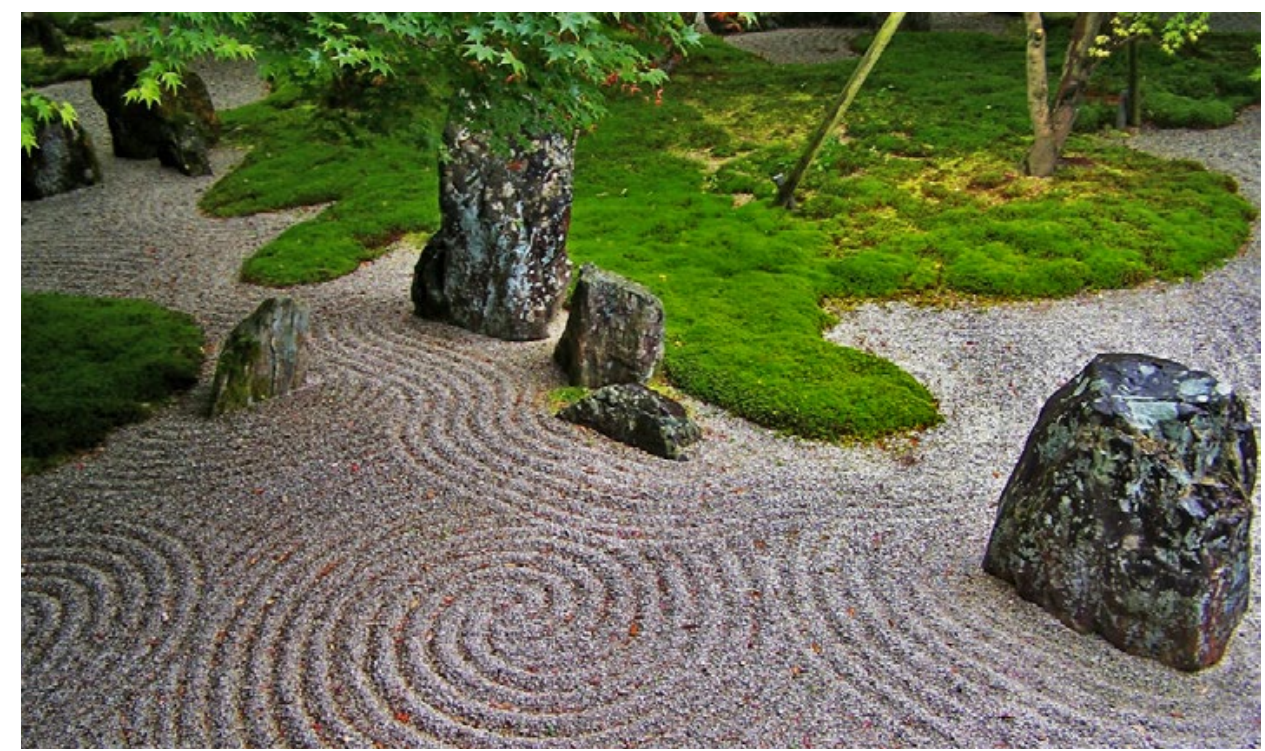

Ryc. 1. Ogród Zen. Źródło ilustracji: wikipedia.pl

Fig. 1. Zen garden. Illustration Credit: wikipedia.pl 
Jak można stwierdzić wnioskując po przykładach historycznych założeń ogrodowych, „Idea ogrodu leczniczego jest konceptem nowym i nienowym"4. Mimo wielowiekowej tradycji projektowania ogrodów i uniwersalnym właściwościom zdrowotnym przyrody, docenionym przez rozmaite kraje i kultury, wraz z rozwojem cywilizacyjnym i czysto technologicznym podejściem do procesu leczenia, zależność pomiędzy zdrowiem człowieka a kontaktem z otaczającą go przyrodą została zdewaluowana.

W pojęciu ogólnym, proces dochodzenia do zdrowia kończy się w momencie osiągnięcia przez chorego stanu dobrego samopoczucia. Jest to wielowymiarowy proces regeneracji ciała zarówno w stopniu fizycznym, jak i psychicznym, dodatkowo wzbogaconym o kwestie duchowe, emocjonalne czy społeczne. Nawet pochodzenie angielskiego słowa „heal” oznaczającego zdrowienie wywodzi się od staro-angielskiego „haelon”, oznaczającego całość, kompletność - co z kolei sugeruje złożoność i wielopłaszczyznowość procesu dochodzenia do zdrowia. Zatem pomysł zaprojektowania środowiska które, powodowałoby w pacjencie poczucie komfortu, bezpieczeństwa i spokoju byłoby pomocne, jako uzupełnienie klasycznej terapii i z pewnością wpłynęłoby korzystnie na jej efekty. Idea leczniczych ogrodów stopniowo wraca do łask szczególnie w krajach Ameryki Północnej. Założenia ogrodowe przeznaczone jako ogrody lecznicze są często spotykane w obrębie lub w najbliższym sąsiedztwie budynków opieki zdrowotnej: szpitali, oddziałów psychiatrycznych, przy szkołach dla dzieci niepełnosprawnych, czy hospicjach. Ogrody lecznicze dedykowane są głownie osobom chorym, starszym, bądź niepełnosprawnym, i projektowane są z uwzględnieniem ich specjalnych potrzeb, tak aby były dla nich łatwo dostępne fizycznie, lub przynajmniej łatwo obserwowane $z$ okien pomieszczeń. Nie są to jednak przestrzenie przeznaczone wyłącznie dla osób chorych, bądź przechodzących rekonwalescencję. $Z$ ogrodów często korzystają również pracownicy placówek, jak i goście, którzy chętniej spędzą czasz bliskimi na łonie przyrody, niż na szpitalnym oddziale. Główną zaletą ogrodu zdrowia jest jego wpływ na poziom hormonów stresu. Samo zjawisko pojawienia stresu jest zupełnie naturalną fizjologiczną reakcją organizmu na bodziec stresujący, niemniej utrzymywanie się tego stanu przez dłuższy okres może prowadzić do wielu chorób powiązanych ze stresem, np: kłopoty z przemianą materii, układem krążenia i neurologicznym. Sam stan chorobowy jest okolicznością wielce stresującą. Jak dowiedziono zarówno empirycznie przez wieki rozwoju cywilizacyjnego, jak i naukowo, przebywanie w pobliżu natury pomaga obniżyć stres i osiągnąć stan spokoju. Psychologia środowiskowa ${ }^{6}$ wyjaśnia iż ciągłe obciążenie umysłu, bez możliwości odnowy i wypoczynku, w konsekwencji prowadzi do problemów na podłożu psychologicznym. Objawiać się to może spadkiem koncentracji, nadwrażliwością i częstą irytacją, co w rezultacie skutkuje w wydłużeniu czasu rekonwalescencji pacjenta. Ta teoria potwierdza, że szczególne cechy natury, mogą mieć korzystny wpływ na proces zdrowienia i rekonwalescencji.

Bezpośredni kontakt człowieka z przyrodą, umożliwiony przez zapewnienie udogodnień ułatwiających bliski kontakt $\mathrm{z}$ naturą może mieć kluczowy wpływ na przebieg leczenia, jak i oszczędzić pacjentowi nadmiernego obciążenia psychicznego stanem chorobowym. Dostęp do natury pomaga w wyrównaniu rytmu serca, obniża ciśnienie krwi i sprzyja wchłanianiu witamin. Ogrody lecznicze, kreujące poczucie przebywania w bliskim kontakcie z naturą mogą być (i często są) odpowiedzią, w jaki sposób pomóc radzić sobie ze stresem i zmęczeniem, zarówno chorym, personelowi medycznemu, jak i osobom zdrowym.

4 Cooper M., 1999. Historical and cultural perspective on healing gardens. John Wiley \& Sons, Nowy Jork, Thumaczenie autorskie.

5 Gesler W., 1998. Putting health into place: landscape, identity and well-being, Syracuse University Press, Syracuse.

6 Kaplan S., 1995. The Restorative Benefits of nature: Toward an Integrative framework, Journal of Environmental Psychology. 
Pozytywny wpływ ogrodów leczniczych na psychofizyczny stan zdrowia pacjenta, jak i na skrócenie całkowitego czasu koniecznego do pełnego wyzdrowienia zauważono i doceniono głównie w krajach Ameryki Północnej. Na etapie planowania infrastruktury szpitali i budynków opieki zdrowotnej, zaczęto przeznaczać dodatkowe miejsce na zaprojektowanie ogrodu, a w obiektach istniejących re-aranżowano przestrzeń w taki sposób, by ogród się tam pojawił. Przykładem takiego projektu może być Graham Garden ${ }^{7}$ w Victorii w Kanadzie. Ogród przy tamtejszej placówce pożądany był już od dłuższego czasu, jednak założono go dopiero w połowie lat dziewięćdziesiątych XX wieku. Znajduje się on pomiędzy dwoma skrzydłami budynku szpitalnego. Blisko dziewięćdziesiąt procent pacjentów placówki porusza się na wózkach, a cześć z nich cierpi na chorobę Alzheimera. Głównym założeniem projektowym było stworzenie przyjaznej przestrzeni, służącej do ćwiczeń, uprawy roślin i do odpoczynku od przygnębiającej rutyny dnia codziennego w domu opieki. Głównym elementem ogrodu jest strumień z pomostem, dodający głębi przestrzeni, która musi być płaska z racji na użytkowników o ograniczonej mobilności. Oprócz strumienia jest również miejsce na ognisko, kwietniki i grządki możliwe do pielęgnacji siedząc na wózku inwalidzkim, a także rzeźby pomagające w orientacji w przestrzeni ogrodu. Zaprojektowane są również altany i pergole, dające cień w słoneczne dni. Projekt kreuje również przestrzeń, przypominającą wiejskie pejzaże, ze stawami i górami, przez co buduje złudzenie znacznie większego niż jest w rzeczywistości. Główny nacisk kładzie jednak na dostępność i komfort użytkowników.

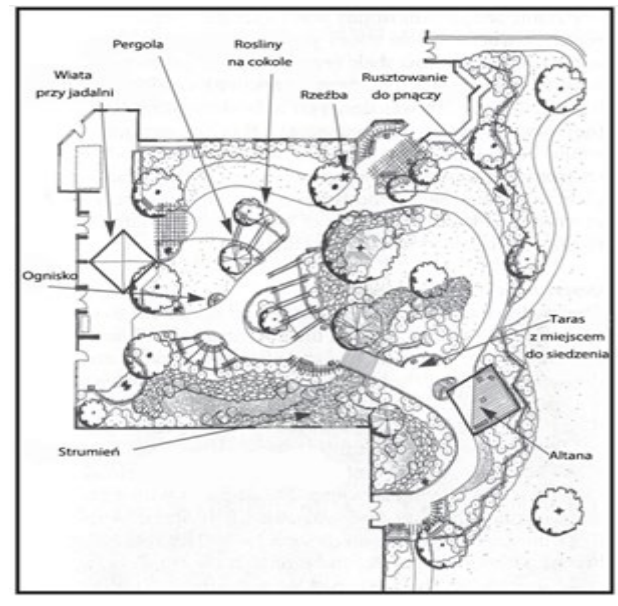

Ryc. 2. Plan ogrodu Graham Garden

Fig. 2. Plan of the Graham Garden Źródło ilustracji; Cooper M.,1999. Historical and cultural perspective on healing gardens

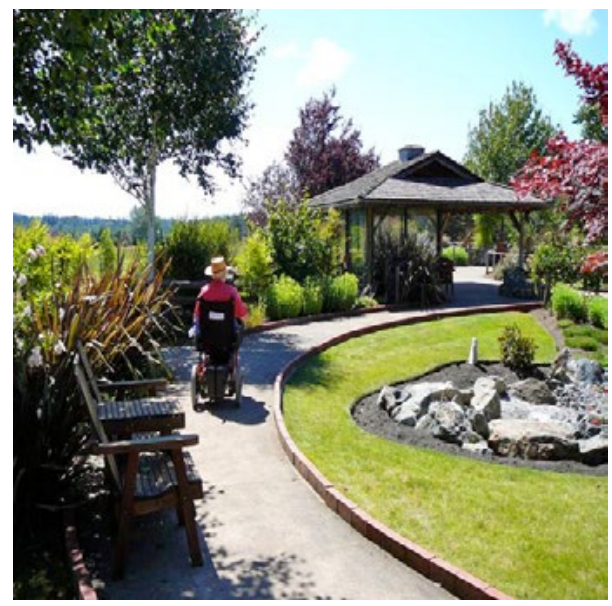

Ryc. 3 Widok ogrodu Graham Garden

Fig. 3. View of the Graham Garden Illustration Credit; Cooper M.,1999. Historical and cultural perspective on healing gardens.

Innym bardzo dobrym przykładem ogrodu leczniczego jest założony w 2008 roku Swedish Covenant Hospital Garden w Chicago. Ogród zaprojektowany został przez architekt Marię Smithburg, a jego głównym celem miało być zapewnienie dobrego samopoczucia zarówno pacjentom, ich rodzinom, jak i całej społeczności szpitala. W ogrodzie znajduje się wiele ścieżek spacerowych, fontann, ławek i strumieni. Znajduje się też labirynt, pobudzający wyobraźnię i zachęcający do aktywności. Detal architektoniczny wykonany jest jedynie z naturalnych i lokalnych materiałów, pomagający utrzymać wrażenie niezakłóconego kontaktu z naturą. W tym ogrodzie pacjenci są w stanie zredukować stres i napięcie, towarzyszące chorobie, jak

7 Cooper M., 1999. Historical and cultural perspective on healing gardens. John Wiley \& Sons, Nowy Jork. 
i poczuć wrażenie naturalnego porządku i kontroli nad środowiskiem. Motto szpitala Swedish Covenant brzmi „Wiedza, ku lepszemu samopoczuciu”, co świadczy o misji szpitala skupionej na wszystkich aspektach procesu zdrowienia, w tym poczuciu spokoju, porządku i bezpieczeństwa, zapewnianym m.in. przez szpitalny ogród.

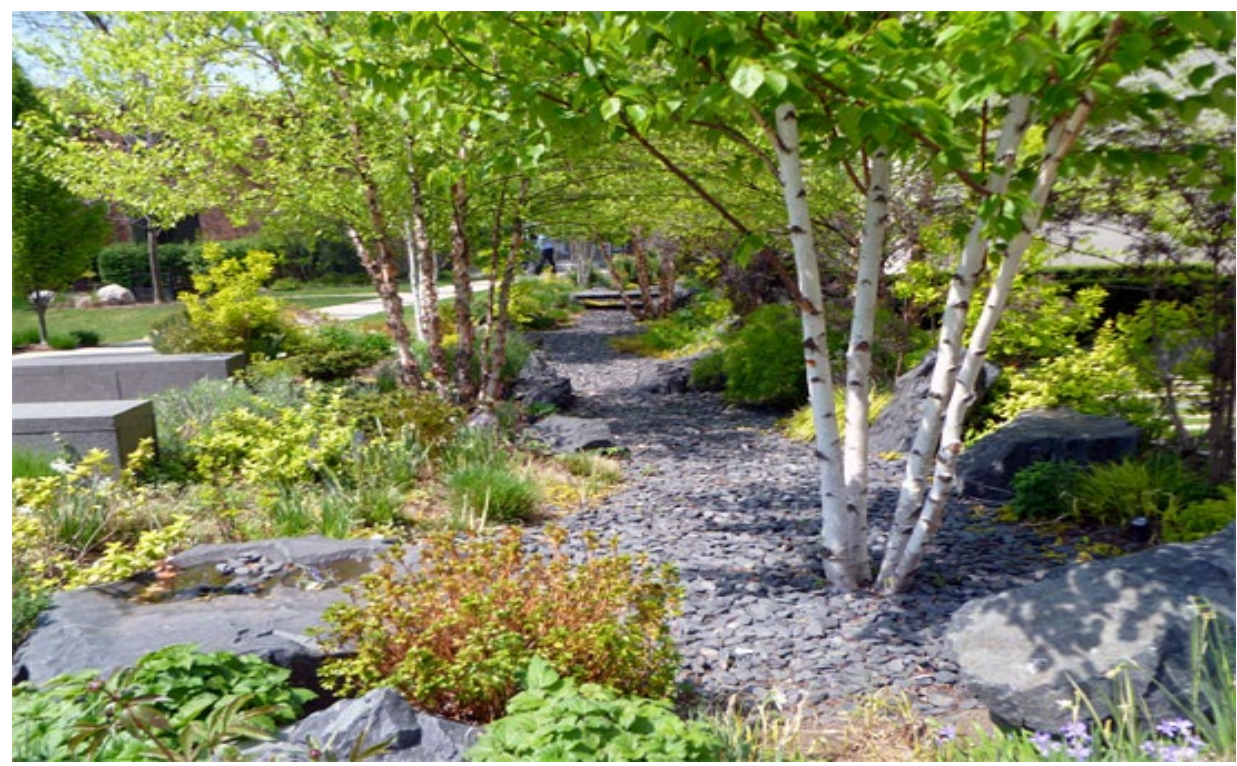

Ryc. 4. Ogród Swedish Covenant Hospital Garden w Chicago. Źródło ilustracji: wikipedia.pl

Fig. 4. Swedish Covenant Hospital Garden Garden in Chicago. Illustration Credit: wikipedia.pl

W Polsce, ilość projektowanych przy budynkach ochrony zdrowia ogrodów leczniczych jest znikoma. Rola tych przestrzeni nie została jeszcze należycie doceniona, a wiedza o sposobie ich komponowania nie jest powszechna wśród projektantów. Ważne jest aby planowanie przyszpitalnych przestrzeni zielonych stało się normą, zarówno wśród architektów, jak i lekarzy, świadomych pozytywnego ich wpływu na terapię. Aby poprawnie zaprojektować ogród leczniczy, należy przede wszystkim poznać grupę docelową, która będzie użytkować daną przestrzeń, poznać ich specjalne potrzeby i ich ograniczenia. Jest niezbędne, aby określić czy ogród będzie miejscem różnych ćwiczeń i innych aktywności, czy będzie użytkowany w mniej aktywny sposób. Najważniejszym zadaniem ogrodu leczniczego jest wywołanie poczucia spokoju i bezpieczeństwa. Osoby chore i zdrowiejące są wyjątkowo narażone na czynniki stresogenne, mogą być podatne na zmiany nastroju i stany depresyjne. W związku z tym ogród przyszpitalny powinien być zaprojektowany w sposób przywołujący jedynie jednoznacznie pozytywne konotacje. Ogród musi być łatwo dostępny zarówno w przestrzeni całego założenia projektowego budynków towarzyszących, jak i dostępne powinny być wszystkie zaprojektowane w nim przestrzenie. Powinien wzbudzać poczucie samodzielności i niezależności, szczególnie w osobach osłabionych chorobą, bądź niepełnosprawnych. Zróżnicowanie i różnorodność przestrzeni zachęci do podejmowania samodzielnych decyzji o sposobie spędzenia czasu. Ważne jest pokazanie że ogród jest bytem żywym, rosnącym, naturalnym i zmieniającym się. Obfitość zieleni, ruch płynącej wody, czy nawet obecność małych zwierząt (np. zwabionych do karmnika ptaków) będzie wzbudzało wśród pacjentów pozytywne emocje. Zastosowanie w projekcie materiałów surowych, syntetycznych czy przytłaczających w swojej formie, może przynieść efekt zupełnie odwrotny od pożądanego. Ogród powinien również oferować i zachęcać do różnego typu aktywności. Zaprojektowanie przestrzeni, miejsc i urządzeń pobudzających aktywność fizyczną będą miały dodatkowo pozytywny wpływ na proces zdrowienia. 
Dla osób starszych mogą to być odpowiednio zaprojektowane alejki, służące spacerom, jak i miejsca gdzie pacjent mógłby sam doglądać i opiekować się roślinnością czy uczestniczyć w zajęciach z Hortiterapii ${ }^{8}$. Dla młodszych pacjentów i dzieci, mogą to być miejsca karmienia zwierząt, rośliny zwabiające motyle lub otwarte przestrzenie do zabawy. Każda aktywność fizyczna działa pozytywnie-rozpraszająco, pomagając skupić myśli na aktualnie wykonywanej czynności, zamiast na niedogodnościach towarzyszących procesowi zdrowienia. Ogród powinien komunikować się z odwiedzającymi, za pomocą wielu bodźców: widoku, zapachu, czy dźwięku. Chory może słuchać dźwięku kaskady, śpiewu ptaków, dotykać rzeźb, czy nawet smakować owoców Stymulacja zmysłów jest jednym z istotniejszych czynników pobudzających aktywność i mobilizujących do działania9.

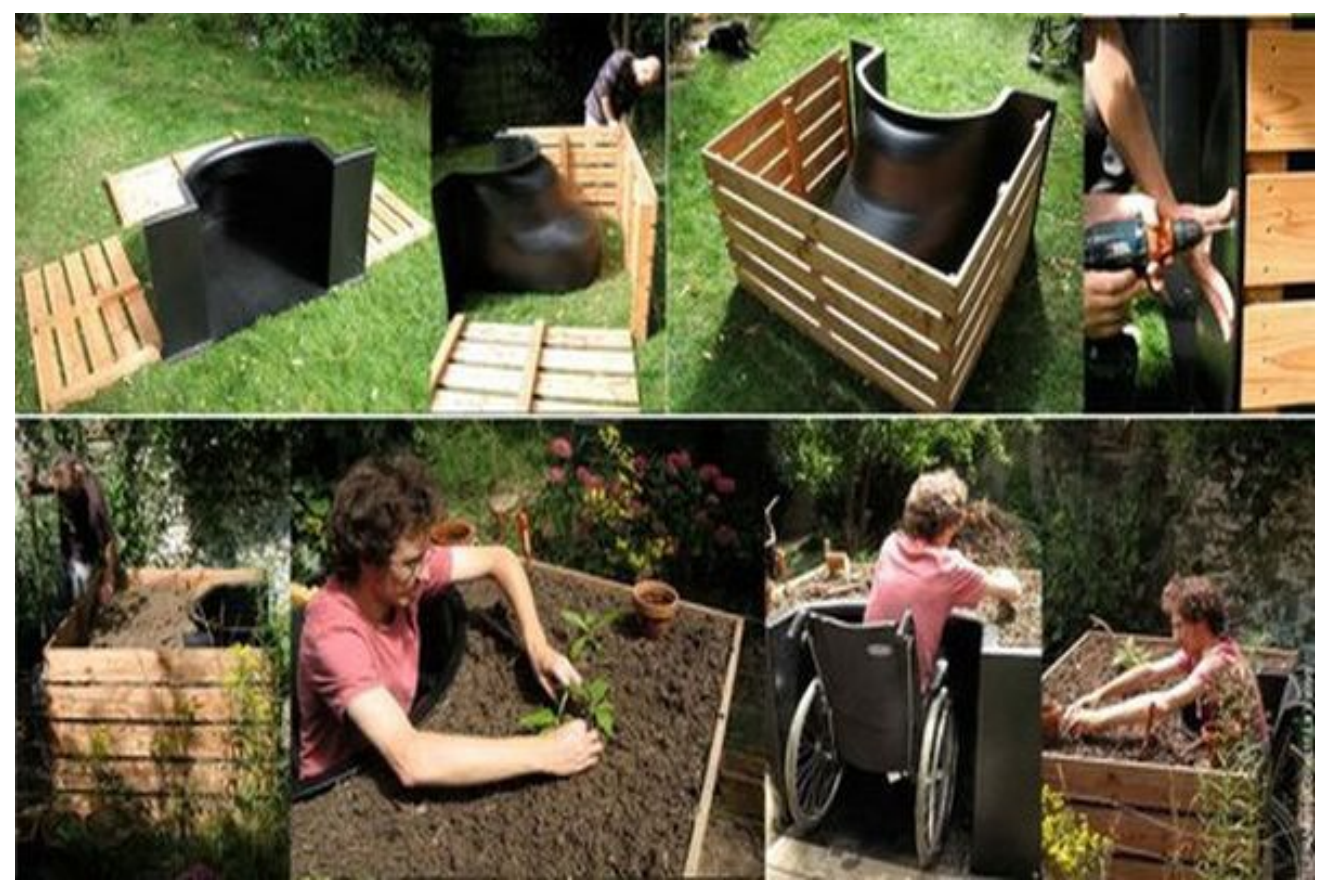

Ryc. 5. Urządzenia wspomagające Hortiterapię, przeznaczone dla osób niepełnosprawnych. Źródło ilustracji: grafika google.

Fig. 5. Assistive horticultural therapy, for people with disabilities. Illustration Credit: Google Images.

Ogród leczniczy powinien wzbudzić w użytkowniku poczucie jedności, azylu i przywiązania. Jeśli osoba poczuje więź z przestrzenią, zechce spędzać właśnie tam swój czas, znajdzie tam swoje bezpieczne miejsce, z dala od wielkomiejskiego zgiełku i niepokoju szpitalnych sal, będzie można śmiało powiedzieć, że ogród leczniczy został prawidłowo zakomponowany i spełnił należycie swoje zadanie.

8 Latkowska M., 2008. Hortiterapia - rehabilitacja i terapia przez pracę w ogrodzie. Zeszyty Problemowe Postępów Nauk Rolniczych.

9 Stigsdotter U., Grahn P., 2002. What makes a garden a healing garden? Journal of Therapeutic Horticulture. 


\title{
PIŚMIENNICTWO
}

Cooper M., 1999. Historical and cultural perspective on healing gardens. John Wiley \& Sons, Nowy Jork.

Gesler W., 1998. Putting health into place: landscape, identity and well-being, Syracuse, Syracuse University Press.

Hensel W., Tabaczyński S., 1978. Rewolucja neolityczna i jej znaczenie dla rozwoju kultury europejskiej. Zakład Narodowy im. Osolińskich, Wrocław-Warszawa-Kraków-Gdańsk.

Latkowska M.,2008. Hortiterapia - rehabilitacja i terapia przez pracę w ogrodzie. Zeszyty Problemowe Postępów Nauk Rolniczych.

Kaplan S., 1995. The Restorative Benefits of nature: Toward an Integrative framework, Journal of Environmental Psychology.

Rybczyński W., 1999. A Clearing in the Distance: Frederick Law Olmsted and North America in the Nineteenth Century. Nowy Jork.

Stigsdotter U. i Grahn P., 2002. What makes a garden a healing garden? Journal of Therapeutic Horticulture,

Szolginia W., 1992. Architektura: Sigma NOT, Warszawa.

\section{HEALING GARDENT AS A WAY OF AIDING THERAPY}

\begin{abstract}
Being close to nature always had a positive impact on human health and well-being. From the Neolithic Revolution, which began 10,000 years before our era and the start of the transition from hunting and gathering to sedentary life, people began to ascribe mystical powers to sacred gardens, groves or rock formations. In the Middle Ages, gardens were often placed near monasteries. Herbal ones for purely pragmatic, therapeutic function and recreational gardens, as places for contemplation and reverie. With the development of civilization, the presence of gardens amongst the human settlements has become a permanent part of the landscape. Their beneficial effect on the psyche and human health, as well as purely aesthetic qualities has been appreciated. With the development of modern medical techniques, the role of healing gardens has been marginalized, or entirely omitted. In Poland, medical gardens, along with hospitals and clinics are not considered an essential element of their architecture. There is a need for public education, also among architects, to force a trend, focusing on designing healing gardens along with hospital buildings. Health benefits for the patients are disproportionate to the economic costs. Yet health is the most valuable.
\end{abstract}

Key words: public space, landscape design, healing gardens, stress, health rehabilitation, treatment 